\title{
Lung Stem Cell Update: Promise and Controversy
}

\author{
I.P. Neuringer, S.H. Randell
}

ABSTRACT: Lung Stem Cell Update: Promise and Controversy. I.P. Neuringer, S.H. Randell.

Currently, there is great enthusiasm about potential stem cell therapies for intractable diseases. We previously reviewed the topic of stem cells in lung injury and repair, including the role of endogenous, tissue (somatic) stem cells and the contribution of circulating cells to the lung parenchyma. Our purpose here is to provide a concise update in this fast-moving field. New information and ongoing debate focus attention on basic issues in lung stem cell biology and highlight the need for additional studies to establish the feasibility of cell therapies to prevent or treat lung diseases.

Monaldi Arch Chest Dis 2006; 65: 1, 47-51.

Keywords: Somatic stem cells, transdifferentiation, embryonic stem cells.

Division of Pulmonary and Critical Care Medicine; Departments of Medicine and Cellular and Molecular Physiology; The University of North Carolina; Chapel Hill, North Carolina, USA.

Correspondence: Scott H. Randell, Ph.D.; UNC Cystic Fibrosis Center, CB 7248; Room 4011 Thurston-Bowles Building; Chapel Hill, NC, USA 27599; e-mail: randell@med.unc.edu

The concept of transdifferentiation, here defined as the ability of a cell from one tissue type to generate differentiated cells of another tissue type, is highly controversial. Specifically, there is debate surrounding the ability of circulating bone marrow derived cells to generate lung-specific cell types. Such transdifferentiated cells can either contribute to the development of pathology, as in fibrosis, or may be able to serve a protective function, as in endothelial or epithelial regeneration. Publications highly relevant to lung stem and progenitor cells, postdating our prior review [1], are summarized in table 1 . We apologize in advance for any studies omitted due to oversight or space limitations. Furthermore, we did not exhaustively critique technical aspects of many of the studies individually. It is important to remember that, where applicable, each article variably characterized the starting cell populations, that technical standards for determination of cell origin and phenotype by imaging methods are in flux, and that few if any articles have shown clonal expansion of transdifferentiated lung cells. Our general approach in this brief update, with some exceptions, is to state the take home message of the study. We recommend that critical analysis of each paper is necessary to decide how well the data supports the conclusions.

Lung somatic stem cells. There are new data regarding local cell renewal within distinct anatomic and cellular lung compartments. Kim et al. identified a regional bronchio-alveolar epithelial stem cell population, confined to the junction between airway and alveoli and expressing characteristic markers, which was capable of clonal multi-potential growth, including generation of adenocarcinoma [2]. The extent of the proximal airway and distal alveolar epithelium supported by this stem cell niche remains to be determined. Starting with mixed populations of dissociated tissue cells from 3 adult human bronchi, Sabatini et al. cultured fibroblasts that displayed markers common to bone marrow stromal cells (MSCs), that retained the ability to follow adipogenic, chondrogenic, or osteogenic lineages and may contribute to lung repair and remodeling [3]. Summer et al. analyzed embryonic mouse lung side population cells, capable of dye efflux analogous to bone marrow hematopoietic stem cells (HSCs), and characterized them as a complex mixture of both hematopoietic (CD 45+) and non-hematopoietic (CD 45-) progenitors, the latter containing both smooth muscle or endothelial progenitors that when co-cultured formed tubular, vessel-like structures [4]. The molecular characteristics and full differentiation potential of the CD 45- lung side population cells require further study.

Transdifferentiation. Bone marrow cells of traditional hematopoietic lineages normally migrate to the lungs, and this process is dramatically accelerated in lung injury and pathology. Leukocytes characteristic of acute and chronic inflammatory processes are undoubtedly physiologically important, but the ability of circulating cells to generate lung-specific cell types by fusion or transdifferentiation is hotly debated, fueled by both supportive and negative studies. In general, the contribution of bone marrow to lung is directly correlated with the degree of lung injury, typically ablative radiation prior to bone marrow transplant followed by experimental injury in animals, or injury accompanying bone marrow or lung transplantation in people. Abe et al. created para- 
Table 1. - Recent studies addressing lung somatic stem cells and generation of lung cell types by exogenous progenitors or ES cells

\begin{tabular}{|c|c|c|c|c|c|}
\hline $\begin{array}{l}\text { Study } \\
\text { Type }\end{array}$ & $\begin{array}{l}\text { Disease } \\
\text { or Model }\end{array}$ & $\begin{array}{l}\text { Tissue } \\
\text { of Origin }\end{array}$ & $\begin{array}{l}\text { Lung Cell Type Formed } \\
\text { / Frequency }\end{array}$ & $\begin{array}{l}\text { Method } \\
\text { of Detection }\end{array}$ & Ref. \\
\hline $\begin{array}{l}\text { Animal, } \\
\text { in-vivo }\end{array}$ & Not applicable & Not applicable & $\begin{array}{l}\text { Putative bronchiole-alveolar epithelial } \\
\text { stem cell, co-expresses CCSP and SPC, } \\
\text { increased in oncogenic K-ras mouse } \\
\text { tumor model }\end{array}$ & $\begin{array}{l}\text { Immunohistochemistry, } \\
\text { Cell culture of purified cells }\end{array}$ & {$[2]$} \\
\hline $\begin{array}{l}\text { Human } \\
\text { in-vivo } \\
\text { and in-vitro }\end{array}$ & Not applicable & Not applicable & $\begin{array}{l}\text { MSC-like bronchial fibroblast } \\
\text { that generates adipogenic, chondrogenic, } \\
\text { or osteogenic lineages }\end{array}$ & Flow cytometry and RT-PCR & {$[3]$} \\
\hline $\begin{array}{l}\text { Animal, } \\
\text { in-vivo }\end{array}$ & BMT & $\begin{array}{l}\text { Embryonic mouse lung side } \\
\text { population }\end{array}$ & $\begin{array}{l}\text { HSCs, endothelial cells, and smooth } \\
\text { muscle cells }\end{array}$ & $\begin{array}{l}\text { Immunohistochemistry, FACS, } \\
\text { RT-PCR, cell culture }\end{array}$ & {$[4]$} \\
\hline $\begin{array}{l}\text { Animal } \\
\text { in-vivo }\end{array}$ & Parabiotic mice & Partner mouse & $\begin{array}{l}\text { Hematopoeitic cells, epithelial cells, } \\
\text { fibroblasts }\end{array}$ & $\begin{array}{l}\text { FACS, immunohistochemistry, } \\
\text { in-vitro culture }\end{array}$ & {$[5]$} \\
\hline $\begin{array}{l}\text { Animal, } \\
\text { in-vivo }\end{array}$ & $\begin{array}{l}\text { Bleomycin injury, } \\
\text { myelosuppression }\end{array}$ & MSCs & $\begin{array}{l}\text { Fibroblasts, type I and type II cells, } \\
\text { endothelium }\end{array}$ & Immunohistochemistry & {$[6]$} \\
\hline $\begin{array}{l}\text { Animal, } \\
\text { in-vivo }\end{array}$ & $\begin{array}{l}\text { Polidoconol injury } \\
\text { and BMT }\end{array}$ & Side-population HSCs & $\begin{array}{l}0.83 \% \text { Y chromosome/cytokeratin+ } \\
\text { epithelial cells }\end{array}$ & $\begin{array}{l}\text { FACS, RT-PCR, FISH, } \\
\text { immunohistochemistry }\end{array}$ & {$[7]$} \\
\hline $\begin{array}{l}\text { Animal, } \\
\text { in-vivo }\end{array}$ & $\begin{array}{l}\text { LPS-induced lung } \\
\text { injury }\end{array}$ & $\begin{array}{l}\text { Fetal liver, whole bone } \\
\text { marrow }\end{array}$ & $\begin{array}{l}\text { Alveolar epithelium and endothelium, } \\
\sim 10 \% \text { total GFP+ }\end{array}$ & $\begin{array}{l}\text { Flow cytometry } \\
\text { and immunohistochemistry }\end{array}$ & {$[8]$} \\
\hline $\begin{array}{l}\text { Human, } \\
\text { in-vivo }\end{array}$ & Pneumonia & Bone marrow & $\begin{array}{l}\text { Reduced circulating endothelial cells } \\
\text { in patients developing fibrosis }\end{array}$ & $\begin{array}{l}\text { Di-acLDL, lectin, VEGF2, } \\
\text { and CD31 expression }\end{array}$ & {$[9]$} \\
\hline $\begin{array}{l}\text { Animal, } \\
\text { in-vivo }\end{array}$ & $\begin{array}{l}\text { Monocrotaline } \\
\text { pulmonary arterial } \\
\text { hypertension }\end{array}$ & $\begin{array}{l}\text { Endothelial-like progenitor } \\
\text { cells, +/- eNOS expression }\end{array}$ & $\begin{array}{l}\text { Endothelium of arterioles, reversal } \\
\text { of hypertension }\end{array}$ & Microangiography, RT-PCR & {$[10]$} \\
\hline $\begin{array}{l}\text { Human } \\
\text { in-vivo }\end{array}$ & $\begin{array}{l}\text { Human acute } \\
\text { lung injury }\end{array}$ & $\begin{array}{l}\text { Circulating endothelial cell } \\
\text { progenitors }\end{array}$ & $\begin{array}{l}\text { Increased progenitors associated with } \\
\text { improved survival }\end{array}$ & $\begin{array}{l}\text { Cell culture, Di-acLDL } \\
\text { and lectin stain }\end{array}$ & {$[11]$} \\
\hline $\begin{array}{l}\text { Animal } \\
\text { in-vivo }\end{array}$ & Elastase lung injury & $\begin{array}{l}\text { Endotracheal GFP+ } \\
\text { embryonic fibroblasts }\end{array}$ & $\mathrm{GFP}+$ fibroblasts present for 20 days & $\begin{array}{l}\text { Immunohistochemistry, } \\
\text { Northern blot }\end{array}$ & {$[12]$} \\
\hline $\begin{array}{l}\text { Human, } \\
\text { in-vitro }\end{array}$ & Co-culture & $\begin{array}{l}\text { MSCs and airway epithelial } \\
\text { cells }\end{array}$ & $\begin{array}{l}\text { Cytokeratin } 18 \text { positive cells expressing } \\
\text { CFTR from MSCs }\end{array}$ & $\begin{array}{l}\text { Immunohistochemistry, } \\
\text { RT-PCR, Cl- efflux assay }\end{array}$ & {$[13]$} \\
\hline $\begin{array}{l}\text { Animal, } \\
\text { in-vivo }\end{array}$ & $\begin{array}{l}\text { BMT and } \\
\text { naphthalene }\end{array}$ & $\begin{array}{l}\text { Stroma and total marrow } \\
\text { from wild type mice }\end{array}$ & $\begin{array}{l}0.01 \% \text { of airway epithelial cells positive } \\
\text { for CFTR }\end{array}$ & $\begin{array}{l}\text { Y chromosome FISH, RT-PCR } \\
\text { and FACS }\end{array}$ & {$[14]$} \\
\hline $\begin{array}{l}\text { Human, } \\
\text { in-vivo }\end{array}$ & $\begin{array}{l}\text { Human lung } \\
\text { transplant }\end{array}$ & Sex-mismatched transplant & $\begin{array}{l}\text { Bronchial } \sim 1.4 \% \text { and alveolar } \sim 3.6 \% \\
\text { chimerism, no cell fusion }\end{array}$ & $\begin{array}{l}\text { Y chromosome FISH, } \\
\text { immunohistochemistry }\end{array}$ & {$[15]$} \\
\hline $\begin{array}{l}\text { Human, } \\
\text { in-vivo }\end{array}$ & $\begin{array}{l}\text { Human lung } \\
\text { transplant }\end{array}$ & Sex-mismatched transplant & Type II cells, $\sim 0.55 \%$ & $\begin{array}{l}\text { Y chromosome FISH, } \\
\text { immunohistochemistry }\end{array}$ & {$[16]$} \\
\hline $\begin{array}{l}\text { Human } \\
\text { in-vivo }\end{array}$ & $\begin{array}{l}\text { Human lung } \\
\text { and BMT }\end{array}$ & Sex-mismatched transplant & $\begin{array}{l}\text { Type II cells, macrophages, endothelium, } \\
\text { qualitative }\end{array}$ & $\begin{array}{l}\text { Y chromosome FISH, } \\
\text { immunohistochemistry }\end{array}$ & {$[17]$} \\
\hline $\begin{array}{l}\text { Animal, } \\
\text { in-vivo }\end{array}$ & BMT & $\begin{array}{l}\text { Whole BM, HSC from } \\
\text { SPC-GFP mice }\end{array}$ & No donor lung cell types expressing GFP & Flow cytometry, RT-PCR & {$[19]$} \\
\hline $\begin{array}{l}\text { Animal, } \\
\text { in-vivo }\end{array}$ & BMT & $\begin{array}{l}\text { Whole BM, HSC from } \\
\text { SPC-GFP, and LacZ mice }\end{array}$ & $\begin{array}{l}\text { No donor lung cell types expressing GFP } \\
\text { or LacZ }\end{array}$ & $\begin{array}{l}\text { Immunohistochemistry, } \\
\text { deconvolution microscopy, } \\
\text { flow cytometry }\end{array}$ & {$[20]$} \\
\hline $\begin{array}{l}\text { Animal, } \\
\text { in-vivo }\end{array}$ & $\begin{array}{l}\text { Endotoxin or } \mathrm{NO} 2 \\
\text { lung injury }\end{array}$ & $\begin{array}{l}\text { Sex-mismatched, } \\
\text { GFP+ whole bone marrow }\end{array}$ & Alveolar epithelium $\sim 0.5 \%$ & $\begin{array}{l}\text { FISH for Y chromosome, } \\
\text { immunohistochemistry }\end{array}$ & {$[21]$} \\
\hline $\begin{array}{l}\text { Animal, } \\
\text { in-vitro }\end{array}$ & $\begin{array}{l}\text { In-vitro } \\
\text { differentiation }\end{array}$ & ES cells & Airway epithelium & $\begin{array}{l}\text { Immunohistochemistry, } \\
\text { RT-PCR, Western blotting }\end{array}$ & {$[22]$} \\
\hline $\begin{array}{l}\text { Animal, } \\
\text { in-vitro }\end{array}$ & $\begin{array}{l}\text { In-vitro } \\
\text { differentiation }\end{array}$ & ES cells & Type II cells & RT-PCR & {$[23]$} \\
\hline $\begin{array}{l}\text { Animal, } \\
\text { in-vitro }\end{array}$ & $\begin{array}{l}\text { In-vitro } \\
\text { differentiation }\end{array}$ & ES cells & Type II cells & Histology, RT-PCR & {$[24]$} \\
\hline $\begin{array}{l}\text { Animal, } \\
\text { in-vitro }\end{array}$ & $\begin{array}{l}\text { In-vitro } \\
\text { differentiation }\end{array}$ & ES cells & Type II cells & Histology, RT-PCR & {$[25]$} \\
\hline \multicolumn{6}{|c|}{$\begin{array}{l}\mathrm{BM}=\text { bone marrow, BMT = bone marrow transplant (with prior ablation), CCSP = Clara cell specific protein, } \mathrm{CFTR}=\text { cystic fibrosis transmembrane regulator protein, } \\
\text { Di-acLDL = di-acetylated low density lipoprotein, eNOS = endothelial nitric oxide synthase, ES = embryonic stem cells, FISH = fluorescence in situ hybridization, } \\
\text { FACS = fluorescence activated cell sorting, GFP = enhanced green fluorescent protein, HLA = human leukocyte antigen, HSC = hematopoietic stem cells, LacZ = } \\
\text { gene for beta galactosidase, MSC = bone marrow stromal cells, adherent bone marrow cells, SCNT = somatic cell nuclear transfer (therapeutic cloning), SPC = } \\
\text { surfactant protein C, VEGF2 = vascular endothelial growth factor } 2 .\end{array}$} \\
\hline
\end{tabular}


biotic pairs of mice, one ubiquitously expressing green fluorescent protein (GFP) and the other, wild type [5]. After injuring the lungs of the wild type mice, they observed GFP-positive hematopoietic and lung parenchymal cell types. GFP-positive, fibroblast-like cells were cultured from the wild-type lungs, but their clonal growth or ability to be passaged was not assessed. Rojas and colleagues found that myelo-suppression increased homing and localization of a mixed, CD 45-depleted population of donor MSCs to bleomycin-injured lung, where they reportedly differentiated into fibroblasts, type I and type II alveolar epithelium, and endothelium [6]. After host irradiation and transplantation of bone marrow side population cells highly enriched for their stem cell potential, MacPerson et al. detected Y chromosome-positive donor cells expressing cytokeratin at a frequency of $0.8 \%$ in recipient lung tissue [7]. Yamada et al. found that LPS-induced lung inflammation recruited bone marrow derived progenitor cells, which reportedly differentiated into endothelial and epithelial cells and protected the lung [8]. In parallel, these investigators identified circulating endothelial cell progenitors in humans with bacterial pneumonia, which were reduced in number when fibrosis ensued, further suggesting a role for bone marrow derived cells in lung repair [9]. Work by the group of Dr. Stewart showed that bone marrow-derived endothelial-like progenitor cells reversed monocrotaline-induced pulmonary arterial hypertension in rats [10], and this preclinical data has supported a human trial of endothelial progenitor cell therapy for pulmonary hypertension (http://www.stemcellnetwork.ca/news/articles.php ?id=889). A recent study suggests that increased numbers of circulating endothelial-like progenitor cells are associated with survival in human acute lung injury [11]. Thus, while the actual prospects remain unknown, pulmonary endothelial cell supplementation with putative circulating progenitors to treat or reverse vascular injury is at the forefront of potential lung cell therapies. Also of note regarding cell therapy is that embryonic mouse lung fibroblasts instilled down the trachea of elastasetreated mouse lungs apparently penetrated into the lung interstitium, where they persisted for 20 days [12]. The prospects for treatment of lung diseases characterized by epithelial dysfunction with bone marrow-derived stem cells are less certain, and hinge on the controversy surrounding the extent of transdifferentiation, again here defined as the generation of cells of one tissue type by cells of a different tissue type. Wang and colleagues procured MSCs from cystic fibrosis (CF) patients, introduced a correct copy of the CFTR gene, and cocultured them with airway epithelial cells from $\mathrm{CF}$ patients [13]. The studies suggested that CFTR gene-corrected MSCs converted into airway epithelium and promoted chloride transport. However, the magnitude of the correction in comparison to normal chloride transport in non-CF epithelial cells was not determined. In fact, a very recent study in CFTR gene-deleted mice illustrated that transdifferentiation followed by CFTR protein ex- pression was extremely rare, occurring in $0.01 \%$ of epithelial cells [14], arguing against the feasibility of bone marrow transplantation to treat $\mathrm{CF}$.

Sex-mismatched human bone marrow and lung transplantation provides an opportunity to assess transdifferentiation, and recent studies again yielded conflicting results. Spencer et al. examined serial biopsies from 2 boys receiving female lung allografts and suggested significant tissue chimerism, namely, $1.6 \%$ and $3.6 \%$ of airway and alveolar Y chromosome-positive epithelial cells, respectively [15]. On the other hand, Zander et al., using a similar approach, typically found only one Y chromosome-positive, cytokeratin-positive alveolar epithelial cell, estimated to be $0.5 \%$ of alveolar epithelium, in 9 of 25 specimens [16]. Albera et al. studied 8 lungs from female donors transplanted into male recipients, then explanted at re-transplantation for chronic rejection, and also 3 lungs at autopsy from females receiving male bone marrow transplants [17]. Their results were completely qualitative, but suggested the possibility of exogenous cells contributing to lung epithelium. Common to many investigations in this field, these studies all rely on finicky and somewhat subjective staining and imaging techniques, in this case made even more difficult by variable tissue sampling, post mortem changes, and/or the length of fixation.

Recent studies have revisited earlier animal experiments that initially supported a bone marrow contribution to lung parenchymal cells. Kotton et al. used mice expressing GFP driven by the surfactant protein $\mathrm{C}$ (SPC) promoter, which is a specific reporter system for alveolar type II cells [18]. They transplanted bone marrow cells from these mice into lethally irradiated adult mice, which were then treated with bleomycin [19]. Similarly, Chang et al. studied neonatal mice following bone marrow transplantation from donors ubiquitously expressing marker genes or from SPC-GFP mice [20]. The investigators carefully employed flow cytometry, deconvolution microscopy, and SPC gene expression and reported the absence of alveolar epithelial reconstitution by whole bone marrow or HSCs. The results from both studies suggest that artifactual co-localization of markers, in the face of a flood of phagocytic hematopoietic cell types, many dead cells, and abundant autofluoresence in lung tissue, is more likely than actual transdifferentiation. Another recent study in mice reports absence of significant parenchymal engraftment of marrow-derived cells after endotoxin or $\mathrm{NO}_{2}$ lung injury [21]

The literature to date highlights the technical difficulty of definitively establishing transdifferentiation of bone marrow-derived stem cells into lung parenchymal cell types. We suggest that further studies solely relying on imaging will not help to resolve the controversy, and that additional approaches such as those illustrated in figure 1 will be necessary. The ability to culture parenchymal cell types of exogenous derivation from recipient lung, as illustrated in figure $1 \mathrm{~A}$, would be supportive of transdifferentiation. Since typical hematopoietic lineage cell types can persist for many days in cul- 


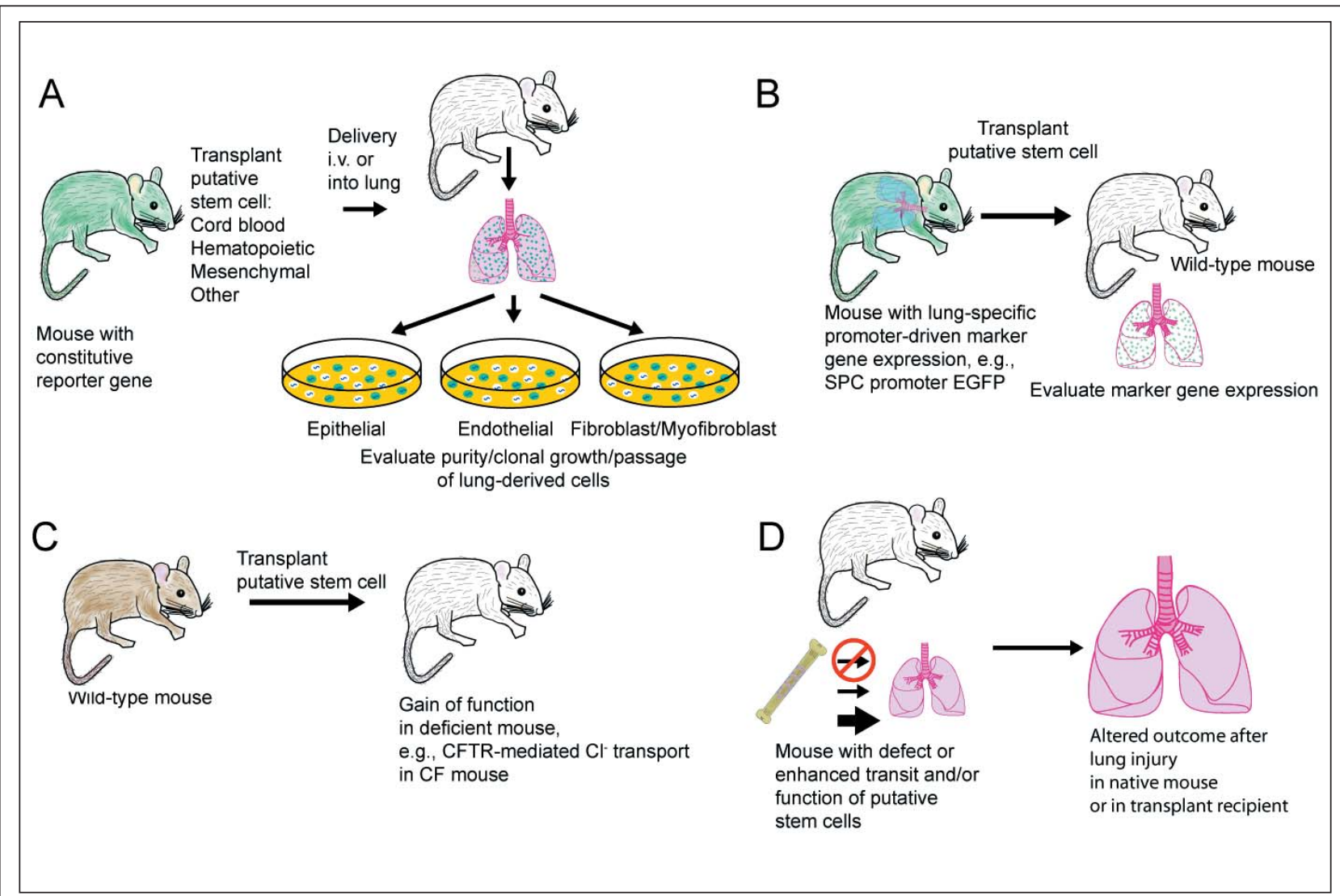

Fig. 1. - Functional approaches to determine the contribution of exogenous, circulating cells to the lung parenchyma. See text for further explanation.

ture, clonal growth and sub-passaging comparable to endogenous lung cells would be stronger proof. Furthermore, this method can theoretically be applied to human transplant tissues. The approach of using donor cells with a reporter driven by a lung specific promoter (figure 1B) has already been tried, but with negative results $[19,20]$. However, false negatives are possible, and additional studies using different constructs, donor populations, injuries, etc. are warranted. Unequivocal gain of function in a deficient mouse (figure 1C), for example CFTR mediated chloride transport in CF mice, would obviously be precedent-setting. Finally, generation of mice with enhanced or depleted function of putative exogenously-derived lung cells, and demonstration of an altered outcome after lung injury in either the native lung or in recipients of bone marrow transplants from the mutant mice, would provide functional evidence (figure 1D). It is important to note that, whether transdifferentiation of exogenous cells to lung cell types is ultimately deemed fact or fancy, circulating cells are likely integral, if not vital, to healing and strongly contribute to lung remodeling.

Embryonic stem cell (ES) generation of lung cells. Pluripotent ES cells offer promise as a potential source of lung endoderm, mesoderm, and ectoderm cell types. Murine embryonic stem cells grown as embryoid bodies, and then on collagen coated surfaces with growth factors, followed by replating at an air-liquid-interface developed into an epithelium with Clara, ciliated, basal, and intermediate cells [22]. Additional studies explored conditions promoting mouse ES cell expression of Type II cell genes [23-25]. Similar studies with human ES cells are likely imminent. Although an intial report of somatic cell nuclear transfer (SCNT, therapeutic cloning) to create human ES cells that were pluripotent, chromosomally normal, and with DNA and immunological haplotype identical to the donor specimen has now been discredited [26], it is likely that this technique will ultimately be applied to humans. Respiratory epithelium is commonly observed in teratomas derived from human ES cells, and the ultimate success of SCNT with human cells will enable study and potentially therapeutic employment of a patient's own cells. Recent advances and setbacks highlight opportunities for novel lung research using ES cells and the need for more studies to determine the practical relevance and safety of using ES cells for cell therapy.

In summary, many challenges remain to better understand endogenous lung stem cells, to determine the role of exogenous cells in lung injury, repair and pathology, and to explore the potential uses of ES cells. Developing rational strategies for lung protective or regenerative cell therapy will require an intensive and scientifically rigorous effort.
Acknowledgements: The authors thank Dr. Susan Majka for critical review of the manuscript and stimulating discussions and Lisa Brown for excellent graphics, editorial and production assistance. 


\section{References}

1. Neuringer IP, Randell SH. Stem cells and repair of lung injuries. Respir Res 2004; 5: 6.

2. Kim CF, Jackson EL, Woolfenden AE, et al. Identification of bronchoalveolar stem cells in normal lung and lung cancer. Cell 2005; 121: 811-813.

3. Sabatini F, Petecchia L, Tavian M, Jodon de Villeroche V, Rossi GA, Brouty-Bove D. Human bronchial fibroblasts exhibit a mesenchymal stem cell phenotype and multilineage differentiating potentialities. Lab Invest 2005; 85: 962-971.

4. Summer R, Kotton DN, Liang S, Fitzsimmons K, Sun $\mathrm{X}$, Fine A. Embryonic lung side population cells are hematopoietic and vascular precursors. Am J Respir Cell Mol Biol 2005; 33: 32-40.

5. Abe S, Boyer C, Liu X, et al. Cells derived from the circulation contribute to the repair of lung injury. Am J Respir Crit Care Med 2004; 170: 1158-1163.

6. Rojas M, Xu J, Woods CR, et al. Bone marrow-derived mesenchymal stem cells in repair of the injured lung. Am J Respir Cell Mol Biol 2005; 33: 145-152.

7. MacPherson $\mathrm{H}$, Keir P, Webb S, et al. Bone marrowderived SP cells can contribute to the respiratory tract of mice in vivo. J Cell Sci 2005; 118: 2450.

8. Yamada M, Kubo H, Kobayashi S, et al. Bone marrowderived progenitor cells are important for lung repair after lipopolysaccharide-induced lung injury. J Immunol 2004; 172: 1266-1272.

9. Yamada M, Kubo H, Ishizawa K, Kobayashi S, Shinkawa M, Sasaki H. Increased circulating endothelial progenitor cells in patients with bacterial pneumonia: evidence that bone marrow derived cells contribute to lung repair. Thorax 2005; 60: 410-413.

10. Zhao YD, Courtman DW, Deng Y, Kugathasan L, Zhang Q, Stewart DJ. Rescue of monocrotaline-induced pulmonary arterial hypertension using bone marrow-derived endothelial-like progenitor cells. Efficacy of combined cell and eNOS gene therapy in established disease. Circ Res 2005; 96: 442-450.

11. Burnham EL, Taylor WR, Quyyumi AA, Rojas M, Brigham KL, Moss M. Increased circulating endothelial progenitor cells are associated with survival in acute lung injury. Am J Respir Crit Care Med 2005; 172: 854-860.

12. Kuang PP, Lucey E, Rishikof DC, Humphries DE, Bronsnick D, Goldstein RH. Engraftment of neonatal lung fibroblasts into the normal and elastase-injured lung. Am J Respir Cell Mol Biol 2005; 33: 371-377.

13. Wang G, Bunnell BA, Painter RG, et al. Adult stem cells from bone marrow stroma differentiate into airway epithelial cells: potential therapy for cystic fibrosis. Proc Natl Acad Sci U S A 2005; 102: 186-191.
14. Loi R, Beckett T, Goncz KK, Suratt BT, Weiss DJ. Limited restoration of cystic fibrosis lung epithelium in vivo with adult marrow derived cells. Am J Respir Crit Care Med 2006;173: 171-179.

15. Spencer H, Rampling D, Aurora P, Bonnet D, Hart SL, Jaffe A. Transbronchial biopsies provide longitudinal evidence for epithelial chimerism in children following sex mismatched lung transplantation. Thorax 2005; 60: 60-62.

16. Zander DS, Baz MA, Cogle CR, Visner GA, Theise $\mathrm{ND}$, Crawford JM. Bone marrow-derived stem-cell repopulation contributes minimally to the type II pneumocyte pool in transplanted human lungs. Transplantation 2005; 80: 206-212.

17. Albera C, Polak JM, Janes S, et al. Repopulation of human pulmonary epithelium by bone marrow cells: a potential means to promote repair. Tissue Eng 2005; 11: 1115-1121.

18. Roper JM, Staversky RJ, Finkelstein JN, Keng PC, O'Reilly MA. Identification and isolation of mouse type II cells on the basis of intrinsic expression of enhanced green fluorescent protein. Am J Physiol 2003; 285: L691-L700.

19. Kotton DN, Fabian AJ, Mulligan RC. Failure of bone marrow to reconstitute lung epithelium. Am J Respir Cell Mol Biol 2005; 33: 328-334.

20. Chang JC, Summer R, Sun X, Fitzsimmons K, Fine A. Evidence that bone marrow cells do not contribute to the alveolar epithelium. Am J Respir Cell Mol Biol 2005; 33: 335-342.

21. Beckett T, Loi R, Prenovitz R, et al. Acute lung injury with endotoxin or No2 does not enhance development of airway epithelium from bone marrow. Mol Ther 2005; 12: 680-686.

22. Coraux C, Nawrocki-Raby B, Hinnrasky J, et al. Embryonic stem cells generate airway epithelial tissue. $A m$ J Respir Cell Mol Biol 2005; 32: 87-92.

23. Rippon HJ, Ali NN, Polak JM, Bishop AE. Initial observations on the effect of medium composition on the differentiation of murine embryonic stem cells to alveolar type II cells. Cloning Stem Cells 2004; 6: 49-56.

24. Van Vranken BE, Romanska HM, Polak JM, Rippon HJ, Shannon JM, Bishop AE. Coculture of embryonic stem cells with pulmonary mesenchyma: A microenvironment that promotes differentiation of pulmonary epithelium. Tissue Eng 2005; 11: 1177-1187.

25. Qin M, Tai G, Collas P, Polak JM, Bishop AE. Cell extract-derived differentiation of embryonic stem cells. Stem Cells 2005; 23: 712-718.

26. Hwang WS, Roh SI, Lee BC, et al. Patient-specific embryonic stem cells derived from human SCNT blastocysts. Science 2005; 308: 1777-1783.

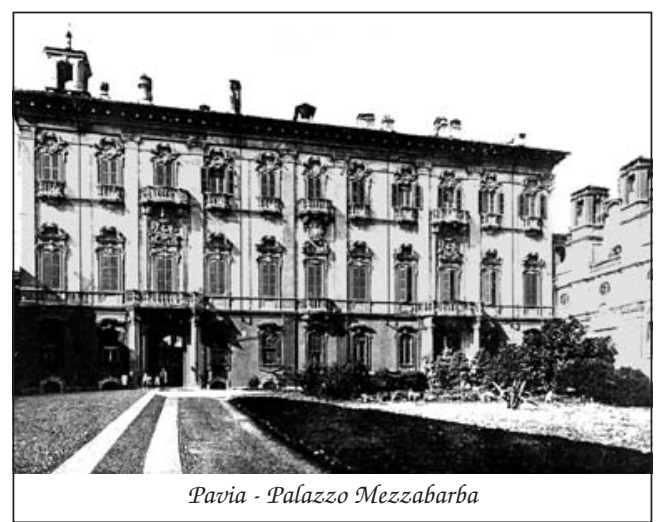

